\title{
OPEN Translesion activity of PrimPol on DNA with cisplatin and DNA-protein cross-links
}

\author{
Elizaveta O. Boldinova ${ }^{1}$, Anna V. Yudkina ${ }^{3}$, Evgeniy S. Shilkin ${ }^{1}$, Diana I. Gagarinskaya ${ }^{1}$, \\ Andrey G. Baranovskiy ${ }^{2}$, Tahir H. Tahirov ${ }^{2}$, Dmitry O. Zharkov ${ }^{3,4}$ \& Alena V. Makarova ${ }^{1 凶}$
}

Human PrimPol belongs to the archaeo-eukaryotic primase superfamily of primases and is involved in de novo DNA synthesis downstream of blocking DNA lesions and non-B DNA structures. PrimPol possesses both DNA/RNA primase and DNA polymerase activities, and also bypasses a number of DNA lesions in vitro. In this work, we have analyzed translesion synthesis activity of PrimPol in vitro on DNA with an 1,2-intrastrand cisplatin cross-link (1,2-GG CisPt CL) or a model DNA-protein crosslink (DpCL). PrimPol was capable of the 1,2-GG CisPt CL bypass in the presence of $\mathrm{Mn}^{2+}$ ions and preferentially incorporated two complementary dCMPs opposite the lesion. Nucleotide incorporation was stimulated by PoIDIP2, and yeast Pol $\zeta$ efficiently extended from the nucleotides inserted opposite the 1,2-GG CisPt CL in vitro. DpCLs significantly blocked the DNA polymerase activity and strand displacement synthesis of PrimPol. However, PrimPol was able to reach the DpCL site in single strand template DNA in the presence of both $\mathrm{Mg}^{2+}$ and $\mathrm{Mn}^{2+}$ ions despite the presence of the bulky protein obstacle.

Correct DNA replication and cell cycle progression requires coordinated work of many enzymes and auxiliary proteins. Human PrimPol is a primase belonging to the archaeo-eukaryotic primase (AEP) superfamily, which possesses both DNA/RNA primase and DNA polymerase activities ${ }^{1,2}$. Emerging evidence suggests the importance of PrimPol role in genome stability maintenance. PrimPol is involved in de novo DNA synthesis downstream of DNA lesions and non-B DNA structures blocking the replication machinery in nuclei and mitochondria ${ }^{3-7}$. PrimPol-dependent reinitiation of DNA synthesis interplays with other DNA damage tolerance pathways such as fork reversal and homologous recombination ${ }^{8,9}$.

Besides its primase activity, PrimPol is capable of bypassing some DNA lesions in vitro suggesting that PrimPol may perform DNA translesion synthesis (TLS). PrimPol efficiently bypasses 8-oxoguanine (8-oxoG), 5 -formyluracil, $\mathrm{O}^{6}$-methylguanine and abasic site in the presence of $\mathrm{Mg}^{2+}$ ions $\mathrm{s}^{1,2,10,11}$. In $\mathrm{Mn}^{2+}$-catalyzed reactions, PrimPol synthesizes through additional blocking lesions such as $1, N^{6}$-ethenoadenine and thymine glycol ${ }^{10}$. PrimPol also bypasses UV-induced lesions: cis-syn T-T dimers (CPD) and T-T (6-4) photoproducts ${ }^{2,5,12}$. It was suggested that PrimPol can "skip" blocking DNA lesions rather than incorporate dNMPs opposite these DNA adducts (so-called "pseudo-TLS" or the template "scrunching" mechanism). It is believed that the primase activity is the primary function of PrimPol in cells ${ }^{4-6}$ but, if a complex damage is present, the situation is possible when during de novo DNA synthesis PrimPol encounters a DNA lesion, and the TLS activity of PrimPol might contribute to the DNA damage tolerance. PrimPol binding to DNA and its activity can be regulated by accessory proteins: replication protein A (RPA) ${ }^{13-15}$ and DNA polymerase $\delta$-interacting protein 2 (PolDIP2) ${ }^{16}$.

DNA cross-links (CL) represent an abundant class of DNA lesions in a genome. They may be formed between bases of one DNA strand (intrastrand CL), bases of different DNA strands (interstrand CL) and between DNA and a protein molecule (DNA-protein CL, DpCL). Among crosslinking agents, cisplatin represents a special interest due to its significance as an antitumor chemotherapy drug ${ }^{17}$. The most common cisplatin-induced Pt-DNA adducts are 1,2-intrastrand CLs between adjacent guanine bases (1,2-GG CisPt CL) (60-65\%) and adjacent adenine and guanine bases (20-25\%). The remaining 10-20\% include monoadducts, 1,3- and 1,4-intrastrand CLs between purines separated by one or two nucleotides, interstrand CLs and DpCLs (reviewed in ${ }^{18}$ ). Cisplatin

\footnotetext{
${ }^{1}$ Institute of Molecular Genetics, National Research Center «Kurchatov Institute», Kurchatov sq. 2, Moscow, Russia 123182. ${ }^{2}$ Eppley Institute for Research in Cancer and Allied Diseases, Fred \& Pamela Buffett Cancer Center, University of Nebraska Medical Center, Omaha, NE 68198, USA. ${ }^{3}$ Institute of Chemical Biology and Fundamental Medicine, Siberian Branch of the Russian Academy of Sciences, 8 Lavrentiev Avenue, Novosibirsk, Russia 630090. ${ }^{4}$ Novosibirsk State University, 2 Pirogova St., Novosibirsk, Russia 630090. ${ }^{\square}$ email: amakarova-img@yandex.ru
} 
adducts represent a block for replicative polymerases ${ }^{19}$. Cisplatin CLs halt DNA replication and induce an initial transient S-phase arrest, which is followed by a persistent G2/M arrest and apoptosis ${ }^{20-22}$. On the other hand, efficient repair, TLS and replication restart might contribute to tumor resistance to cisplatin (reviewed $\mathrm{in}^{23}$ ).

DpCLs can be formed by chemotherapeutic drugs such as cisplatin and some environmental agents (formaldehyde, 1,3-butadiene, hexavalent chromium). DpCLs also can arise from reactions of radicals with DNA, from abortive enzymatic reactions of topoisomerases or generation of AP sites (reviewed in ${ }^{24}$ ). Moreover, several DNA repair proteins can be covalently trapped during base excision repair. DNA-glycosylases (such as Nth, Fpg, NEIL1) and other enzymes with associated lyase activity (such as Pol $\beta$, Pol $\lambda$ or PARP1) may become irreversibly trapped by oxidized or even regular AP sites ${ }^{25-31}$. DpCLs as extremely bulky adducts interfere replication and transcription with lethal consequences if unrepaired ${ }^{32-34}$. Removal of a DpCL from DNA is challenging due to bulkiness of the adducts which interfere sterically with the assembly of the mammalian NER complex ${ }^{35}$. One of proposed pathways for a DpCL removal is proteolytic degradation followed by TLS over a DNA-peptide CL ${ }^{36,37}$.

The DNA polymerase activity of PrimPol on DNA with cisplatin and DNA-protein CLs is yet to be investigated. In this work, we analyzed the ability of PrimPol to replicate past an 1,2-GG CisPt CL and a model DNA-protein crosslinks in vitro. We demonstrated that PrimPol is capable of bypass of the cisplatin CL in the presence of $\mathrm{Mn}^{2+}$ ions and PolDIP2 with low efficiency. Pol $\zeta$ efficiently extended the synthesis beyond the lesion. The synergetic effect of PrimPol, PolDIP2 and Pol $\zeta$ on DNA with the 1,2-GG CisPt CL was more efficient compared to Pol $\kappa$. We also showed that PrimPol is unable to bypass a DpCL neither in the template strand of double-stranded DNA nor in the displaced strand of double-stranded DNA. However, if the substrate contains DpCL in the single-stranded template DNA, PrimPol is able to reach the cross-link site despite the presence of the very bulky protein obstacle. Low yet reproducible primer elongation beyond DpCL was observed in the presence of $\mathrm{Mn}^{2+}$ ions.

\section{Results}

$\mathrm{Mn}^{2+}$ ions stimulate bypass of a 1,2-GG cisplatin CL by PrimPol. To investigate whether PrimPol is capable of incorporating dNTPs opposite the 1,2-GG CisPt CL, we performed primer extension reactions in the presence of $\mathrm{Mg}^{2+}$ or $\mathrm{Mn}^{2+}$ ions. Two primer-template substrates were used: one with the cross-link immediately after the primer end (+1-2) and the other with the cross-link two nucleotides downstream (+3-4), allowing the polymerase to start with incorporation opposite undamaged DNA (Supplementary Figure 1 and Fig. 1A-D). In $\mathrm{Mg}^{2+}$-reactions, PrimPol was completely blocked at the base prior to the lesion in the +3-4 (Fig. 1A, lanes 5-8) and $+1-2$ positions downstream of the primer (Fig. $1 \mathrm{~B}$, lanes $5-8$ ). $\mathrm{Mn}^{2+}$ ions significantly stimulated the DNA polymerase activity of PrimPol (Fig. 1A, lanes 9-12 and Fig. 1B, lanes 9-12) and allowed partial bypass of the 1,2-GG CisPt CL by PrimPol (Fig. 1A, lanes 13-16 and Fig. 1B, lanes 13-16). Noteworthy, PrimPol efficiently incorporated dNMPs opposite both guanines of the 1,2-GG CisPt CL placed at the +1-2 and +3-4 template positions but the extension beyond the DNA adducts was inhibited. The catalytically deficient PrimPol variant carrying the D114A substitution did not show the TLS activity opposite the lesion suggesting that this activity was intrinsic to PrimPol and not a result of contamination (Supplementary Figure 2).

We also compared the TLS activity of PrimPol with Pol $\beta$ and Pol $\eta$. We used different concentrations of DNA polymerases in order to obtain similar levels of the DNA polymerase activity on undamaged DNA (Fig. 1D, lanes 4-6, 16-18 and 22-24). In reactions supporting equal levels of catalytic activity, the dNMPs incorporation opposite the 1,2-GG CisPt CL by PrimPol (Fig. 1D, lanes 1-3, 7-9) was slightly more efficient compared to Pol $\beta$ (Fig. 1D, lanes 13-18) but was less efficient compared to Pol $\eta$ (Fig. 1D, lanes 19-24) $\left(\mathrm{Mn}^{2+}\right.$-containing buffer was used for PrimPol and the buffer with $\mathrm{Mg}^{2+}$ was used for Pol $\beta$ and Pol $\eta$ ).

We also tested the incorporation of individual dNMPs on a DNA substrate with the 1,2-GG CisPt CL (Fig. 1C). PrimPol preferentially incorporated two complementary dCMPs opposite the $3^{\prime}-\mathrm{G}(+1 \mathrm{G})$ and $5^{\prime}-\mathrm{G}$ $(+2 \mathrm{G})$ of the 1,2-GG CisPt CL (Fig. 1C, lane 10), and also incorporated one dTMP opposite the 3'-G (Fig. 1C, lane 9). The ratio of dCMP/dTMP incorporation was 5.6 and 2.3 for undamaged DNA and 1,2-GG CisPt CL, respectively. It is likely that PrimPol incorporates pyrimidine nucleotides directly opposite the 1,2-GG CisPt CL avoiding lesion skipping because the lesion is not flanked by adenines and guanines in DNA template. PrimPol also incorporated two dGMP opposite the 1,2-GG CisPt CL with low efficiency (Fig. 1D, lanes 3 and 8 shows) which could be a result of skipping two $\mathrm{T}$ and incorporation opposite two $\mathrm{C}$ in the downstream template sequence 3'-TTCC.

PrimPol extended the $3^{\prime}$-primer ends with two $\mathrm{C}$ or one $\mathrm{C}$ paired with the 1,2-GG CisPt CL by incorporating dAMP, dTMP or dCMP and one T paired with the $3^{\prime}-\mathrm{G}$ of the lesion by incorporating dCMP or dGMP (Supplementary Figure $3 \mathrm{~A}, \mathrm{~B}, \mathrm{C}$ ). The stretches of $\mathrm{C}$ and $\mathrm{A}$ on DNA template with the lesion were observed. It is likely that multiple dCMP and dAMP insertions resulting in primer expansion are mediated by primer dislocation and slippage and can be templated by the 1,2-GG CisPt CL and $+2-3 \mathrm{TT}$.

PrimPol was also able to incorporate ribonucleotides opposite the 1,2-GG CisPt CL with low efficiency (at high protein concentration) and preferentially incorporated complementary rCMP (Supplementary Figure 3D).

Efficient 1,2-GG cisplatin CL bypass by PrimPol in cooperation with PolDIP2 and Pol $\zeta$. Accessory protein PolDIP2 stimulates the DNA polymerase and strand displacement activities of PrimPol ${ }^{16,38}$. We tested whether PolDIP2 stimulates the TLS activity of PrimPol across the 1,2-GG CisPt CL (Fig. 2). The fulllength nuclear isoform of PolDIP2 was used in experiments. PolDIP2 stimulated the DNA polymerase activity of PrimPol on undamaged DNA and has no contaminating polymerase activity (Supplementary Figure 4). PolDIP2 significantly simulated the incorporation of dNMPs opposite the 1,2-GG CisPt CL (Fig. 2, lanes 19-21) but did not improve the extension beyond the lesion. 
A
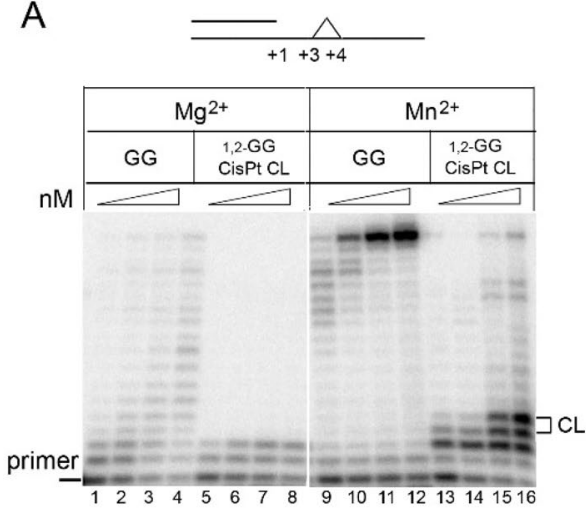

B
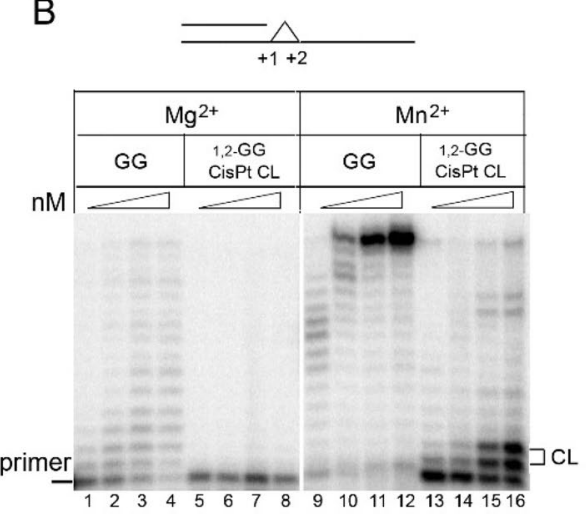

C
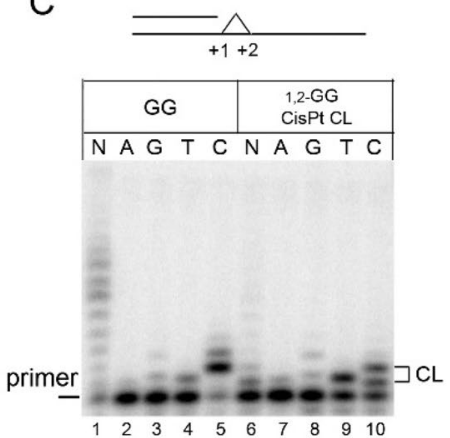
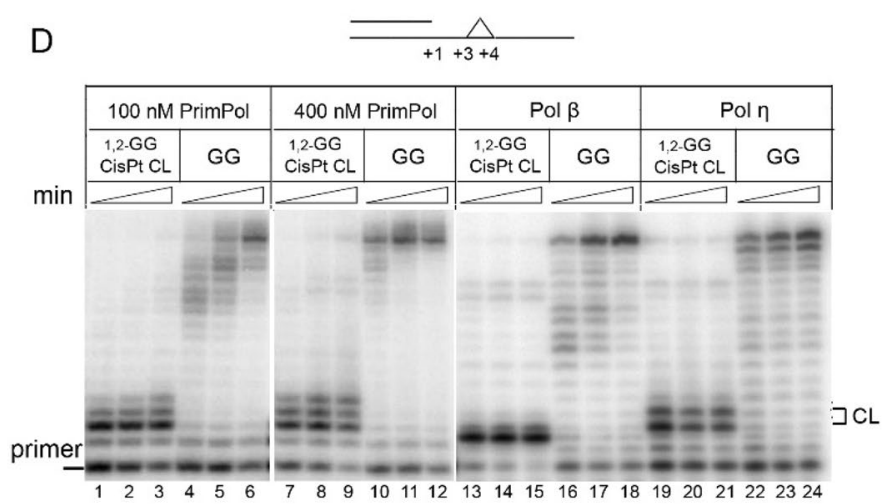

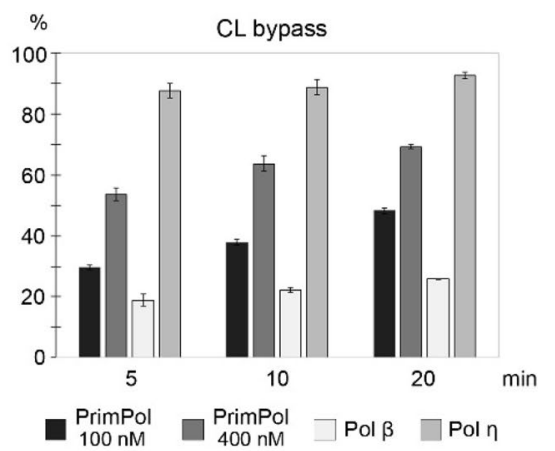

Figure 1. The TLS activity of PrimPol on DNA substrates with the 1,2-GG CisPt CL. (A) The TLS activity of PrimPol on DNA substrates containing the 1,2-GG CisPt CL or undamaged GG at the +3-4 positions downstream of the primer. Reactions were carried out in the presence of $100-600 \mathrm{nM} \mathrm{PrimPol,} 10 \mathrm{mM} \mathrm{MgCl} 2$ or $0.5 \mathrm{mM} \mathrm{MnCl}_{2}$ for $10 \mathrm{~min}$. (B) The TLS activity of PrimPol on DNA substrates with the 1,2-intrastrand cisplatin CL or undamaged GG at the +1-2 position downstream of the primer. Reactions were carried out in the presence of $100-600 \mathrm{nM}$ PrimPol, $10 \mathrm{mM} \mathrm{MgCl}_{2}$ or $0.5 \mathrm{mM} \mathrm{MnCl}_{2}$ for $10 \mathrm{~min}$. (C) dNMPs incorporation on DNA substrate with the 1,2-GG CisPt CL or undamaged GG at the +1-2 position. Reactions were carried out in the presence of $200 \mathrm{nM}$ PrimPol, $0.5 \mathrm{mM} \mathrm{MnCl}_{2}$ for $5 \mathrm{~min}$. Experiments were repeated 3 times. The mean values of the primer extension percentages (PrExt) and the standard errors are indicated. (D) The TLS activity of PrimPol, Pol $\beta$ and Pol $\eta$ on DNA substrate with the 1,2-GG CisPt CL or undamaged GG at the +3-4 position downstream of the primer. Reactions were carried out in the presence of $0.5 \mathrm{mM} \mathrm{MnCl} 2$ (PrimPol) or $10 \mathrm{mM} \mathrm{MgCl} 2$ ( $\mathrm{Pol} \beta$ and Pol $\eta$ ) for 5, 10 or $20 \mathrm{~min}$. The level of the DNA polymerase activity of Pol $\beta(20 \mathrm{nM})$, Pol $\eta(10 \mathrm{nM})$ and PrimPol $(100 \mathrm{nM})$ was similar on undamaged DNA template. The percentage of dNMPs incorporated opposite the 1,2-GG CisPt CL is shown on a diagram.

DNA polymerases Pol $\zeta$ and, in some cases, Pol $\kappa$ efficiently extend DNA primers following nucleotide incorporation at the sites of DNA damage ("extender" polymerases) ) $^{39-42}$. We performed series of primer extension experiments on a DNA template with the 1,2-GG CisPt CL in the presence of PrimPol and combinations of PolDIP2, human Pol $\kappa$ (Supplementary Figure 5) and yeast Pol $\zeta$, which is highly similar to human Pol $\zeta$ (Fig. 2A). Pol $\kappa$ and Pol $\zeta$ carried out efficient full-length DNA synthesis on the undamaged template (Fig. 2, lanes 1-3 and Supplementary Figure 5, lanes 1-3) and partially bypassed the 1,2-GG CisPt CL (Fig. 2, lanes 7-9 and Supplementary Figure 5, lanes 7-9). PolDIP2 slightly inhibited Pol $\kappa$ (Supplementary Figure 5, lanes 10-12) and Pol $\zeta$ activity (Fig. 2A, lanes 10-12).

Next, we performed primer extension reactions with sequential addition of PrimPol (together with PolDIP2) and an extender polymerase: reactions containing PrimPol were initiated with dNTPs, and Pol $\kappa$ or Pol $\zeta$ was added after $10 \mathrm{~min}$. Pol $\zeta$ (Fig. 2A, lanes 16-18) efficiently extended from the PrimPol-generated primer paired with the 1,2-GG CisPt CL. Moreover, addition of Pol $\zeta$ to reactions containing PolDIP2 reduced a pause at the $3^{\prime}-\mathrm{G}$ of the 1,2-GG CisPt CL and significantly improved DNA lesion bypass (Fig. 2A, lanes 22-24). Therefore, the synergistic effect in the bypass of the 1,2-GG CisPt CL in vitro was observed between PrimPol and Pol $\zeta$ (in the presence of PolDIP2). Importantly, Pol $\zeta$ efficiently extended the correctly paired primer with the $3^{\prime}$-end CC opposite the lesion and primer with the $3^{\prime}$-end noncomplementary $\mathrm{T}$ paired with the undamaged $\mathrm{G}$ but paused on DNA substrate containing the mismatched primer with T paired with the $3^{\prime}-\mathrm{G}$ of 1,2-GG CisPt (Fig. 2B). Pol $\kappa$ in combination with PolDIP2 moderately increased the efficiency of the 1,2-GG CisPt CL bypass (Supplementary Figure 5).

CPD is another well-studied example of a cross-link between two adjacent DNA bases. Some translesion DNA polymerases, e.g., Pol $\eta$, efficiently incorporate dNMPs opposite both the $1,2-\mathrm{GG} \mathrm{CisPt} \mathrm{CL}^{43}$ and $\mathrm{CPD}^{44}$. In this 

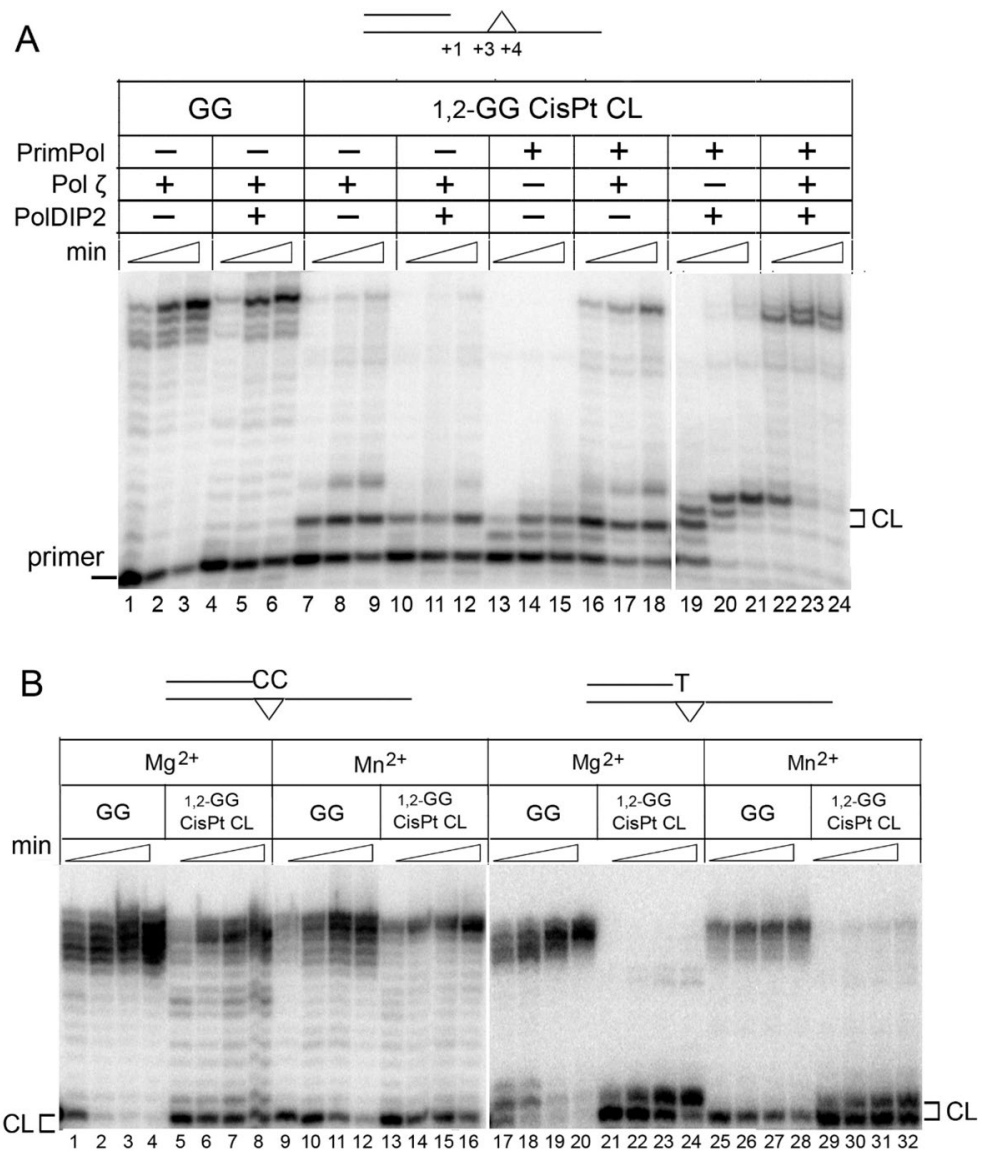

Figure 2. (A) The TLS on DNA substrate with the 1,2-GG CisPt CL by PrimPol in combination with Pol $\zeta$. Reactions were carried out on a DNA substrate with the 1,2-GG CisPt CL at the +3-4 position downstream of the primer in the presence or in the absence of PolDIP2. (B) Extension of correctly paired and mispaired primer termini by Pol $\zeta$. Extension reactions were carried out on DNA substrates with matched primer termini (CC) paired with undamaged GG or the 1,2-GG CisPt CL and mismatched primer with the $3^{\prime}$-end T paired with the $3^{\prime}$-G of the 1,2-GG CisPt CL. Reactions were incubated for 2, 5, 10 and $20 \mathrm{~min}$ in the presence of $10 \mathrm{mM} \mathrm{MgCl}_{2}$ or $0.5 \mathrm{mM} \mathrm{MnCl}_{2}$.

work, we also analyzed the TLS activity of PrimPol on DNA substrate with CPD. Unlike Pol $\eta$, PrimPol alone could not incorporate dNMPs on a DNA substrate with CPD even in the presence of $\mathrm{Mn}^{2+}$ ions (Supplementary Figures 6A and 6B, lanes 13-15). PolDIP2 improved the TLS activity of PrimPol on a DNA substrate with CPD, and partial bypass of CPD was observed in the reactions with PolDIP2 (Supplementary Figures 6A and 6B, lanes 19-21). However, no synergetic effect between PrimPol and Pol $\zeta$ or Pol $\kappa$ was observed either in combination with PolDIP2 or in the absence of PolDIP2 (Supplementary Figures 6A and 6B, lanes 16-18, 22-24). Moreover, the TLS by Pol $\zeta$ was inhibited in the presence of PrimPol and PolDIP2 suggesting that primer termini produced by PrimPol on DNA template with CPD are not a good substrate for elongation by Pol $\zeta$.

The effect of Arg47 and Arg76 mutations on the 1,2-GG CisPt CL bypass. In PrimPol, the active site residues Arg47 and Arg76 contact a phosphate group and the templating base, respectively ${ }^{45}$, and might play a role in the DNA damage bypass. Recently, we have demonstrated that substitutions of either residue attenuate the catalytic activities of PrimPol and formation of the stable PrimPol:DNA complex in the presence of nucleotide substrates ${ }^{46}$. Mutations of both residues also affected the dNMPs incorporation opposite 8-oxoG and undamaged DNA templates. Moreover, it was suggested that the Arg76 residue affects the accommodation of distorting DNA adducts (e.g. CPD) in the active site of PrimPol ${ }^{45}$.

In this work, we analyzed the role of the Arg47 and Arg76 in the TLS activity of PrimPol on DNA with the 1,2-GG CisPt CL. As expected, the R47A substitution decreased the DNA polymerase activity of PrimPol on undamaged and damaged DNA templates whereas the R76A substitution caused almost complete loss of catalytic activity (Fig. 3A). In reactions with equal PrimPol concentrations and time, the R47A substitution decreased the incorporation of dCMP opposite the $5^{\prime}-\mathrm{G}$ of the lesion compared to the wild-type PrimPol (Fig. 3A, lanes 17-20). We increased protein concentration and incubation time to facilitate nucleotide incorporation by the R76A PrimPol mutant to the activity level observed for the wild-type protein. Interestingly, the Arg76 mutation increased the length of DNA products on undamaged DNA (Fig. 3B, lanes 1, 4 and 7) and improved the incorporation of dCMP opposite the $5^{\prime}-\mathrm{G}$ of the 1,2-GG CisPt CL (Fig. 3B, lanes 16-18). The R76A substitution also 
A

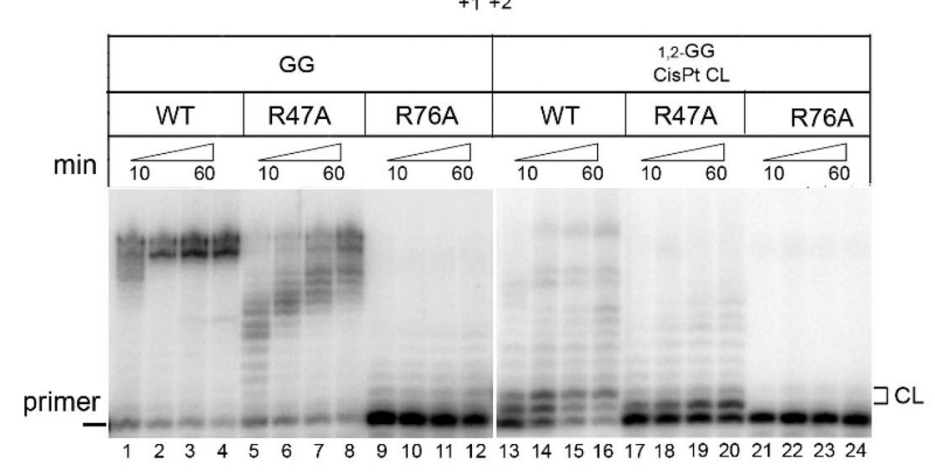

B

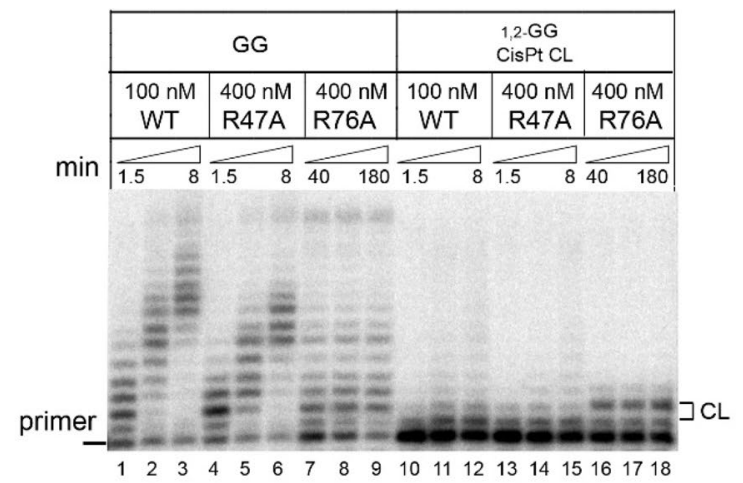

C

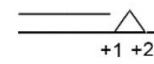

\begin{tabular}{|c|c|c|c|}
\hline \multicolumn{2}{|c|}{ R47A } & \multicolumn{2}{c|}{ R76A } \\
\cline { 1 - 3 } GG & $\begin{array}{c}1,2-G G \\
\text { CisPt CL }\end{array}$ & GG & $\begin{array}{l}1,2-\text { GG } \\
\text { CisPt CL }\end{array}$ \\
\cline { 2 - 3 } & N A G T C N A G T C N G T C N A G T C
\end{tabular}

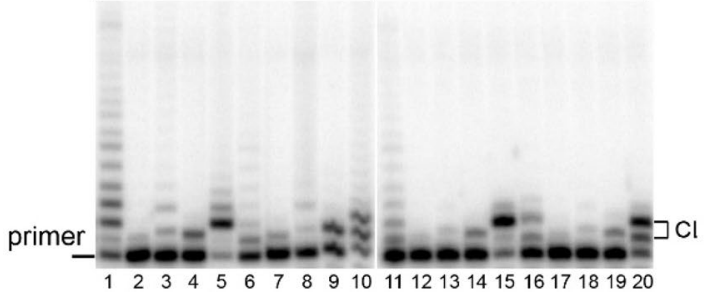

dNMP incorporation

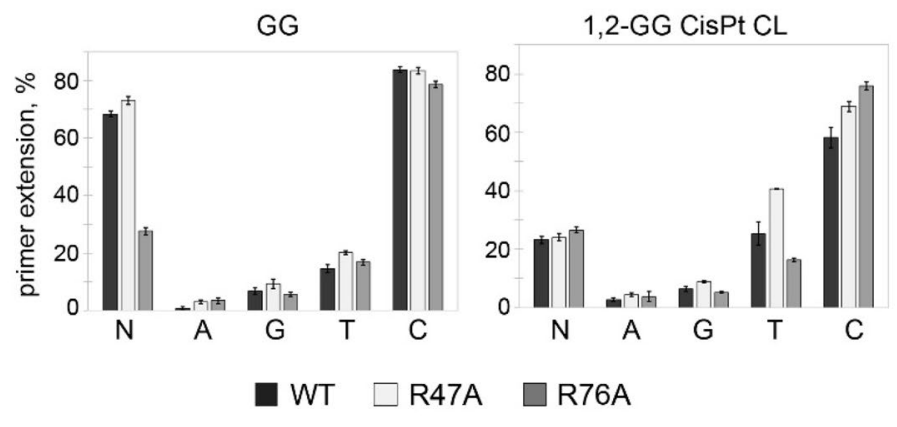

Figure 3. The TLS activity of the R47A and R76A PrimPol variants on DNA substrates with the 1,2-GG CisPt CL. (A) The DNA polymerase activity of PrimPol mutant variants on DNA substrates with the 1,2-GG CisPt CL or undamaged GG at the +1-2 positions. Reactions were carried out in the presence of $200 \mathrm{nM}$ wild-type PrimPol or $200 \mathrm{nM}$ of mutant PrimPol variant for 10, 20, 40 or $60 \mathrm{~min}$. (B) The adjusted DNA polymerase activity of PrimPol mutant variants on DNA substrates with the 1,2-GG CisPt CL or undamaged GG at the + 1-2 positions. Reactions were carried out in the presence of $100 \mathrm{nM}$ wild-type PrimPol for 1.5, 4 or $8 \mathrm{~min}, 400 \mathrm{nM}$ R47A variant for 1.5, 4 or $8 \mathrm{~min}$ and $400 \mathrm{nM}$ R76A variant for 40, 80 and $180 \mathrm{~min}$. (C) dNMPs incorporation opposite undamaged GG or 1,2-GG CisPt CL by the R47A and R76A PrimPol variants. Reactions were carried out in the presence of $200 \mathrm{nM}$ PrimPol for 1 and $4 \mathrm{~min}$ for the wild-type PrimPol, 4 and 8 min for the R47A variant and 10 and 80 min for the R76A variant opposite GG and 1,2-GG CisPt CL, respectively.

decreased the incorporation of noncomplementary dTMP opposite the $3^{\prime}-\mathrm{G}$ of the lesion (Fig. 3C). The ratio of $\mathrm{dCMP} / \mathrm{dTMP}$ incorporation was similar (4.6-4.8) for both undamaged G and the 1,2-GG CisPt CL. These data suggest that the active site residues Arg47 and Arg76 might be important for positioning of damaged nucleobases and facilitate (Arg47) or hinder (Arg76) DNA lesion bypass.

DpCLs block PrimPol. Despite PrimPol's ability to bypass or "skip" a variety of blocking DNA lesions (e.g. $\varepsilon A, C P D, T-T(6-4)$ photoproducts) ${ }^{2,5,10,12}$, full-size DpCLs may present an impassible barrier, as was shown for a variety of DNA polymerases from families A, B, X, and $\mathrm{Y}^{33}$. However, the TLS' activity of PrimPol on DNA with extremely large obstacles such as DpCLs in the template strand is yet to be investigated. Moreover, PrimPol possesses weak strand displacement activity ${ }^{38}$, but no data is availible on the situation when PrimPol displaces downtream strand carrying a DpCL, which is also blocking for other DNA polymerases notwithstanding the undamaged template ${ }^{33}$. Therefore, we investigated the ability of PrimPol to perform synthesis on the substrates containing a DpCL in the template strand of single-stranded DNA (ss-DpCL), in the template strand of doublestranded DNA (temp-DpCL) or in the displaced strand of double-stranded DNA (down-DpCL) (Fig. 4). To create a model DpCL with a defined structure at a pre-determined position, we used the ability of the bifunctional DNA glycosylase Fpg to form a Schiff base reaction intermediate that can be reduced by $\mathrm{NaBH}_{4}$ to produce a stable covalent DNA-Fpg conjugate. The CL site was created at the position +13 from the primer end.

PrimPol was almost fully blocked by an ss-DpCL, and the DNA synthesis was terminated at the position +12 , immediately before the CL site, in the presence of either $\mathrm{Mg}^{2+}$ or $\mathrm{Mn}^{2+}$ ions (Fig. 4, lanes 5-10). Additionally, pauses at the positions +5 in the $\mathrm{Mg}^{2+}$ reactions (Fig. 4, lanes 5-7) and +9 in the $\mathrm{Mn}^{2+}$ reactions (Fig. 4, lanes 5-10) were observed. These primer elongation termination sites located, respectively, 8 and $4 \mathrm{nt}$ upstream of the ss-DpCL can be caused by a clash between the surfaces of PrimPol and Fpg. Interestingly, weak but reproducible bands corresponding to the species longer than $23 \mathrm{nt}$ (primer extended to the position immediately before CL) 


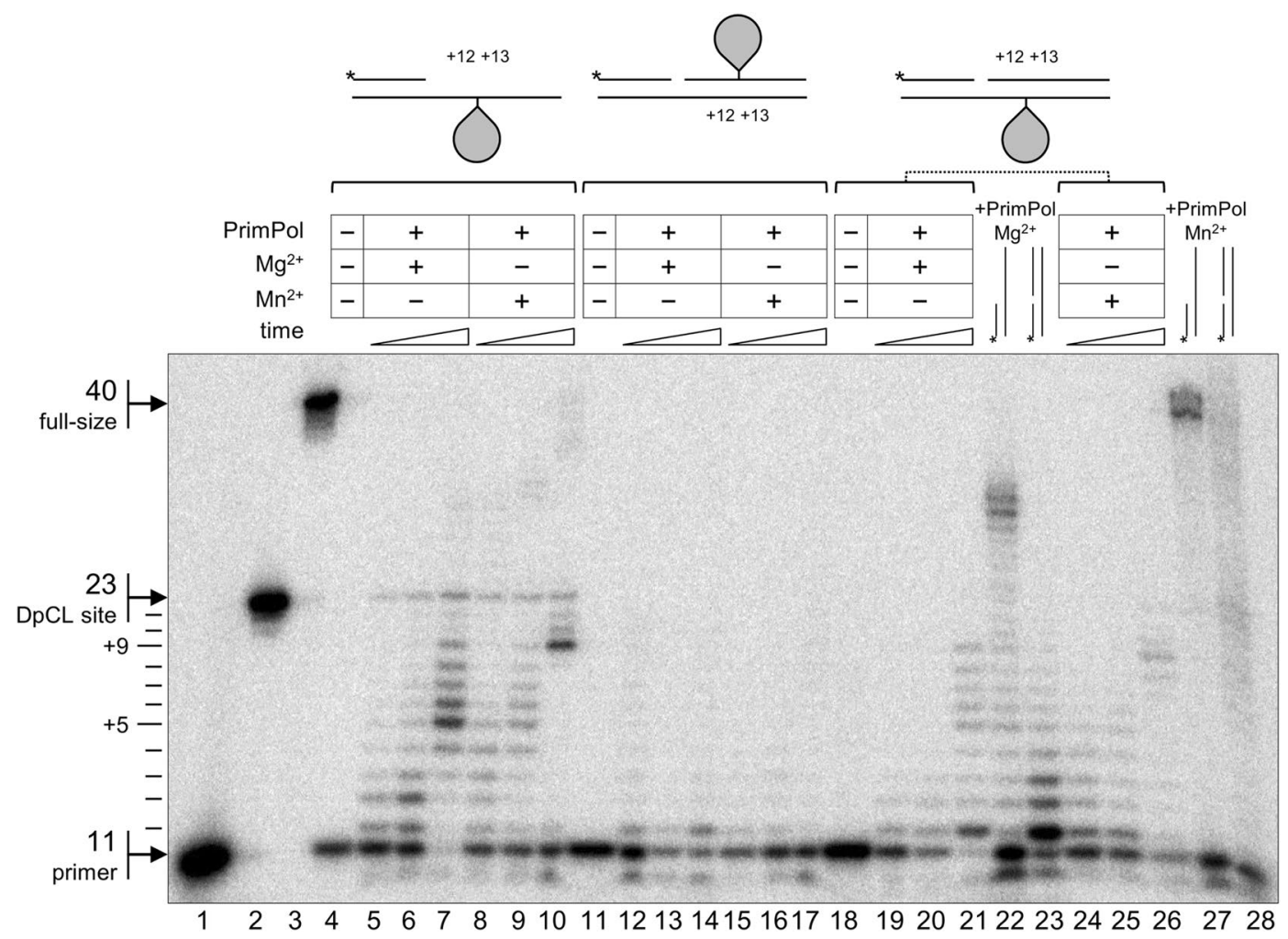

Figure 4. DNA polymerase and strand displacement activities of PrimPol on DNA substrate with a DpCL. Schemes of the DpCL-containing substrates are shown at the top panel. The CL site is located at the +13 position from the 3'-OH of the primer. Lanes 1-3, size markers corresponding to the primer (lane 1, $11 \mathrm{nt}$ long), primer extended to the position immediately before the cross-link site (lane 2, $23 \mathrm{nt}$ ) and full-size product (lane 3, $40 \mathrm{nt}$ ). Lane 4, ss-DpCL without PrimPol, lanes 5-7, ss-DpCL with PrimPol and $\mathrm{Mg}^{2+}$, lanes 8-10, ss-DpCL with PrimPol and $\mathrm{Mn}^{2+}$. Lane 11, down-DpCL without PrimPol, lanes 12-14, down-DpCL with PrimPol and $\mathrm{Mg}^{2+}$, lanes 15-17, down-DpCL with PrimPol and $\mathrm{Mn}^{2+}$. Lane 18, temp-DpCL without PrimPol, lanes 19-21, temp-DpCL with PrimPol and $\mathrm{Mg}^{2+}$, lanes 24-26, temp-DpCL with PrimPol and $\mathrm{Mn}^{2+}$. In all cases, PrimPol extension time points were 2, 5, and $30 \mathrm{~min}$. In lanes 22 and 27, the reaction was carried out with an undamaged primer-template substrate in the presence of $\mathrm{Mg}^{2+}$ (lane 22) or $\mathrm{Mn}^{2+}$ (lane 27), and in lanes 23 and 28, with an undamaged primer-downstream strand-template substrate in the presence of $\mathrm{Mg}^{2+}$ (lane 23) or $\mathrm{Mn}^{2+}$ (lane 28) for $30 \mathrm{~min}$.

were observed in the presence of $\mathrm{Mn}^{2+}$ ions (Fig. 4, lanes 8-10), which might be an evidence of partial ss-DpCL bypass by PrimPol, perhaps by template scrunching.

Remarkably, the ability of PrimPol to elongate the primer with downstream strand displacement strongly depended on the position of the DpCL obstacle ahead. On double-stranded DNA with a DpCL in the template strand, PrimPol possessed weak strand displacement activity and stopped mainly at the position $+9(4$ nt upstream of the CL site; Fig. 4, lanes 19-21 and 24-26). This was comparable with the ability of PrimPol to perform synthesis with strand displacement in the absence of a DpCL (Fig. 4, lane 23). Incorporation of a DpCL in the downstream strand of double-stranded DNA dramatically reduced the efficiency of DNA synthesis with DNA strand displacement by PrimPol in the presence of either $\mathrm{Mg}^{2+}$ or $\mathrm{Mn}^{2+}$ ions (Fig. 4, lanes 12-17). No elongation beyond the CL site was observed.

\section{Discussion}

The TLS activity of PrimPol opposite the 1,2-GG cisplatin CL. Human PrimPol is very special among DNA polymerases. It possesses the DNA primase and DNA polymerase activities ${ }^{1,2}$, anneals DNA strands based on microhomology ${ }^{12}$ and bypasses DNA lesions by incorporating nucleotides opposite damage or by skipping the lesion ${ }^{1,2,5,10-12}$. Avian and human PrimPol-deficient cells demonstrate elevated sensitivity to cisplatin treatment that indicates the role of PrimPol in the tolerance of cisplatin-induced DNA damage ${ }^{3,4,9}$. It was suggested that PrimPol re-initiates stalled replication forks on the leading DNA strand at the sites of blocking DNA lesions such as photoproducts or cisplatin adducts using the DNA primase activity ${ }^{4,5,9}$. However, the situation is possible when during de novo DNA synthesis PrimPol encouners a cisplatin adduct. In this work, we have analyzed the properties of PrimPol on DNA bearing the most common intrastrand cisplatin adduct, 1,2-GG CisPt CL.

The 1,2-GG CisPt CL locally disrupts DNA structure, unwinding the helix and bending the duplex toward the major groove ${ }^{47}$. It represents a strong block to eukaryotic replicative DNA polymerases Pol $\alpha$, Pol $\delta$, and 
Pol $\varepsilon^{19}$ and repair and translesion DNA polymerases Pol $\mathrm{\iota}$ and Pol $\lambda^{48,49}$. Pol $\gamma$ is significantly blocked opposite the 1,2-GG CisPt CL and frequently misincorporates dAMP opposite the $3^{\prime} \mathrm{G}^{50,51}$. Pol $\beta$ preferably incorporates complementary dCMP opposite the $3^{\prime}-\mathrm{G}$ and $5^{\prime}-\mathrm{G}$ with low efficiency but also misincorporates dTMP and dAMP opposite $5^{\prime}$-dG of the 1,2-GG CisPt CL ${ }^{51-53}$. Pol $\eta$ is the most efficient and accurate polymerase opposite the 1,2-GG CisPt CL: Pol $\eta$ preferentially incorporates dCMPs opposite the 3'-G and 5'-G but extension beyond the lesion requires an extender polymerases Pol $\zeta$ or Pol $\kappa^{41,51}$.

In this work, we demonstrate that PrimPol is able to incorporate nucleotides opposite the 5'-G and 3'-G of the 1,2-GG CisPt CL in the presence of $\mathrm{Mn}^{2+}$ ions, and that its activity is stimulated by the accessory protein PolDIP2. Recently, it was shown that PolDIP2 enhances PrimPol binding to DNA ${ }^{16}$, stimulates the processivity of DNA synthesis ${ }^{16}$ and strand displacement activity ${ }^{38}$ as well as increases efficiency and fidelity of 8-oxoG bypass by PrimPol ${ }^{16}$. Our data also support the role of PolDIP2 in the stimulation of the TLS activity of PrimPol. Moreover, PrimPol efficiently synthesized through the 1,2-GG CisPt CL with an assistance of an extender polymerase Pol $\zeta$. Complete bypass of cisplatin lesion in vitro required PrimPol, PolDIP2 and Pol $\zeta$. In this work, we used yeast four-subunit Pol $\zeta$. Human Pol $\zeta$ efficiently extends primer termini pairied with the $1,2-\mathrm{GG}$ CisPt $\mathrm{CL}^{41}$ and its role in resistance to cisplatin and platinum based chemotherapy is well established ${ }^{54,55}$. Yeast Pol $\zeta$ is shown to be an efficient extender of mismatches created by a variety of DNA lesions including DNA crosslinks ${ }^{56-58}$. Thus, we argue that the results obtained with yeast Pol $\zeta$ can be relevant for human Pol $\zeta$. A role of Pol $\kappa$ in tolerance to cisplatin was also suggested ${ }^{59}$. Pol $\kappa$ inefficiently incorporates nucleotides opposite the $1,2-\mathrm{GG}$ Cis-Pt CL but efficiently and accurateley extends DNA primers located at the $3^{\prime}-$ or $5^{\prime}$-G of the lesion ${ }^{60}$. Here, we also showed that Pol $\kappa$ can extend from primer ends generated by PrimPol across from 1,2-GG CL but performs this less efficiently than $\mathrm{Pol} \zeta$.

Altogether, our data show that PrimPol and Pol $\zeta$ carry out fairly accurate TLS acting in concert to bypass the 1,2-GG CisPt CL in vitro. However, the role of the TLS activity of PrimPol opposite cisplatin adducts in vivo is not clear yet. On one hand, chicken $P R I M P O L^{-/-}$DT40 cells are hypersensitive to cisplatin but primase-deficient PrimPol does not suppress the hypersensitivity of $P R I M P O L^{-/}$cells sugesting that its primase, rather than TLS activity, is pivotal for DNA damage tolerance ${ }^{4}$. In human BRCA1-deficent cells, PrimPol promotes repriming and accumulation of internal ssDNA gaps behind forks after cisplatin treatment ${ }^{9}$. Moreover, PrimPol and Pol $\zeta$ contribute to DNA damage tolerance independently of each other in avian cells ${ }^{4}$. On the other hand, PrimPol could contribute to the tolerance of some sub-pool of cisplatin adducts. In this respect, it is interesting that higher amounts of cisplatin-DNA adducts and their poor removal were reported for mitochondrial DNA as compared to nuclear DNA ${ }^{61}$. Since Pol $\gamma$ is not efficient in replicating opposite the 1,2-GG CisPt $\mathrm{CL}^{50}$, but both PrimPol and $\mathrm{Pol} \zeta$ are present in mammalian mitochondria ${ }^{62}$, it is conceivable that the observed TLS activity of PrimPol may play a role in cisplatin tolerance in mitochondria, in addition to the repriming downstream of cisplatin adducts. Future research is needed to explore possible functional interactions between PrimPol and Pol $\zeta$ and the role of PrimPol in TLS across cisplatin adducts in mitochondria.

Like the 1,2-GG CisPt CL, the UV-induced cyclobutane T-T dimer represents an example of a distorting lesion with crosslinked adjacent nucleobases. The efficient TLS activity of PrimPol on the 1,2-GG CisPt CL in the presence of $\mathrm{Mn}^{2+}$ ions was unexpected because the active site of PrimPol does not have enough space for accomodation of CPD and (6-4) T-T photoproducts ${ }^{45}$. The PrimPol active site is relatively constrained in a CPD accommodation model: the 5'-T of the dimer clashes with Gly74 and Arg76 and is forced out of the active site cleft $^{45}$. We analyzed the efficiency of the TLS by PrimPol on a DNA template with CPD in control experiments. Indeed, unlike Pol $\eta$, which efficiently incorporates dNMPs opposite the 1,2-GG CisPt CL and CPD adducts, PrimPol lacked the TLS activity on DNA template with a CPD. In particular, PrimPol failed to incorporate nucleotides opposite CPD and demonstrated poor CPD bypass in the presence of PolDIP2. It is likely that the TLS activity of PrimPol on DNA substrate with CPD observed in some studies is mediated by lesion skipping and depends on the sequence context of the lesion ${ }^{2,5,12}$.

In this work, PrimPol preferentially incorporated two complementary dCMPs opposite guanines of the 1,2GG CisPt CL or inserted one dTMP opposite the 3'-G of the adduct. We suggest that this TLS activity is not mediated by a lesion skipping because ssDNA template lacks microhomology with the $3^{\prime}-\mathrm{C}$ and $3^{\prime}-\mathrm{T}$ primer nucleotides. The mechanism of PrimPol inhibition opposite the 1,2-GG CisPt CL in the presence of $\mathrm{Mg}^{2+}$ ions can be similar with CPD and (6-4) T-T photoproduct ${ }^{5}$ and can involve overlapping of the $5^{\prime}$-base of the crosslink with the side chain of Gly74, Gln75 or Arg76. Indeed, mutation of the Arg76 residue improved the incorporation of complementary dCMP opposite the $5^{\prime}-\mathrm{G}$ on the lesion at the expense of T misincorporation. Structural studies are requried to investigate the mechanism of the 1,2-GG CisPt CL bypass by PrimPol in more detail.

The DNA polymerase and strand displacement activities of PrimPol on DNA with a DpCL. DNA polymerases usually cannot traverse cross-linked protein molecules ${ }^{33,35,63,64}$. However, the behavior of PrimPol or any other AEP superfamily enzyme upon an encounter with a DpCL has never been addressed before. Given the ability of PrimPol to skip strongly blocking base lesions by template scrunching, it was interesting whether the same mechanism could be operating on very bulky DpCLs.

PrimPol demonstrated poor ability to synthesize past the CL site. The best substrate was a primer-template structure with a DpCL in the single-stranded template, in which PrimPol was able to extend the primer until the position immediately before the CL site. Compared with other polymerases, this ability puts PrimPol into one group with B family DNA polymerases from phages (T4 and RB69 polymerases), which can also efficiently utilize a single-stranded template to the last normal nucleotide before a $\mathrm{DpCL}^{33}$. However, pause points were observed a few nucleotides before the CL site. The main factor in stopping the DNA synthesis through DpCL seems to be a clash between the surfaces of an elongating polymerase and the protein obstacle, followed by the protein globule deformation up to the point of incompatibility with substrate binding or catalysis (the "kiss-and-push" 
mode $\left.^{33,65}\right)$. The structure of PrimPol ternary complex with a primer-template and an incoming dNTP ${ }^{45}$ suggests that single-stranded template is kinked by $\sim 90^{\circ}$ when exiting the enzyme's active site. Such an arrangement would presumably minimize collisions of the polymerase with the protein part of a DeL, allowing these two molecules to approach each other closely, while the pause points may correspond to the sites where a steric clash still occurs.

PrimPol demonstrated a moderate ability to displace an undamaged downstream strand but showed striking asymmetry when a DpCL was present in double-stranded DNA. While a DpCL in the template strand decreased the overall efficiency of primer elongation and did not allow the polymerase to reach the CL site, a DpCL in the downstream strand almost completely abrogated strand displacement. This cannot be explained by differences in the CL footprint: judging from the structure of E. coli Fpg cross-linked to DNA ${ }^{66}$, the primer end is 10 nt away from the nearest Fpg surface if the cross-link is in the displaced strand and $8 \mathrm{nt}$ away if it is in the template strand. Although other DNA polymerases cannot pass the Fpg DpCL in the displaced strand, they usually elongate the primer in such substrate better than in the double-stranded template DpCL substrate ${ }^{33}$. This difference may suggest that PrimPol interacts with the downstream DNA in a unique way compared with other DNA polymerases, perhaps extending much farther in the 3'-direction; a structure of PrimPol with a gapped substrate would be required to unravel this conundrum.

In the presence of $\mathrm{Mn}^{2+}$, elongating PrimPol was able to come closer to the DpCL in a single- or doublestranded template compared with $\mathrm{Mg}^{2+}$-dependent reactions. Although $\mathrm{Mn}^{2+}$ is regarded as a divalent cation that lowers the fidelity of DNA polymerases, it does so by increasing both the affinity of polymerases for dNTPs and the efficiency of the catalytic step ${ }^{11,67}$. Therefore, the increased overall efficiency of catalysis in the presence of $\mathrm{Mn}^{2+}$ may promote the advance of PrimPol despite unfavorable steric interactions with the DpCL. Some minor fraction of the polymerase might get hold on the template at the other side of the cross-linked protein molecule and insert a few dNMPs, essentially skipping the obstacle. It remains to be seen whether PrimPol can reprime DNA synthesis beyond a DpCL. Alternatively, this product may reflect a switch of the polymerase into the template-independent mode, which was demonstrated for PrimPol in the presence of $\mathrm{Mn}^{2+68}$.

\section{Methods}

Protein purification. HIS-SUMO-tagged human PrimPol was purified from E. coli Rosetta 2 strain. An overnight culture was grown at $30^{\circ} \mathrm{C}$ and used to inoculate $4 \mathrm{~L}$ of $\mathrm{LB}$ medium. The culture was grown at $30^{\circ} \mathrm{C}$ to $\mathrm{OD}_{600}=0.4$, then the temperature was reduced to $16^{\circ} \mathrm{C}$ and expression was induced with $0.5 \mathrm{mM}$ IPTG for $18 \mathrm{~h}$. Cells were harvested by centrifugation at $9000 \mathrm{rpm}$ for $5 \mathrm{~min}$ at $4{ }^{\circ} \mathrm{C}$. Pellets were resuspended in lysis buffer A (20 mM Tris- $\mathrm{HCl}$ pH 7.9, 2\% glycerol, $100 \mathrm{mM} \mathrm{NaCl}, 10 \mathrm{mM} \mathrm{K}_{(2)} \mathrm{H}_{(2)} \mathrm{PO}_{4}, 4 \mathrm{mM} \beta$-mercaptoethanol, $10 \mu \mathrm{M}$ pepstatin, $10 \mu \mathrm{M}$ leupeptin, $2.5 \mathrm{mM}$ benzamidine, $0.5 \mathrm{mM}$ PMSF) and pulse-sonicated on a Cole Parmer ultrasonic homogenizer for $20 \mathrm{~min}$ (30\% cycle, power 5-6). The cell lysates were clarified by centrifugation at $20,000 \mathrm{rpm}$ for $30 \mathrm{~min}$ at $4{ }^{\circ} \mathrm{C}$ and incubated with Ni-Sepharose beads (GE Healthcare) for $4 \mathrm{~h}$ at $4{ }^{\circ} \mathrm{C}$. The beads were loaded on an empty column and washed with buffer A, followed by washing with buffer B (20 mM Tris$\mathrm{HCl} \mathrm{pH} \mathrm{7.9,2 \%} \mathrm{glycerol,} 100 \mathrm{mM} \mathrm{NaCl}, 10 \mathrm{mM} \mathrm{K}_{(2)} \mathrm{H}_{(2)} \mathrm{PO}_{4}, 4 \mathrm{mM} \beta$-mercaptoethanol, 0,01\% NP-40), buffer $\mathrm{C}\left(20 \mathrm{mM}\right.$ Tris- $\mathrm{HCl} \mathrm{pH}$ 7.9, 2\% glycerol, $100 \mathrm{mM} \mathrm{NaCl}, 10 \mathrm{mM} \mathrm{K}_{(2)} \mathrm{H}_{(2)} \mathrm{PO}_{4}, 4 \mathrm{mM} \beta$-mercaptoethanol, $1 \mathrm{mM}$ ATP, $1 \mathrm{mM} \mathrm{MgCl}$ ) and buffer D $\left(20 \mathrm{mM}\right.$ Tris- $\mathrm{HCl} \mathrm{pH} \mathrm{7.9,2 \%} \mathrm{glycerol,} 400 \mathrm{mM} \mathrm{NaCl}, 40 \mathrm{mM} \mathrm{K}(2) \mathrm{H}_{(2)} \mathrm{PO}_{4}$, $4 \mathrm{mM} \beta$-mercaptoethanol). After the final wash with buffer A, the protein was eluted with buffer $\mathrm{E}(20 \mathrm{mM}$ Tris-HCL pH 7.9, 2\% glycerol, $100 \mathrm{mM} \mathrm{NaCl}, 4 \mathrm{mM} \beta$-ME and $100 \mathrm{mM}$ imidazole). The fractions containing PrimPol were combined and digested overnight at $4{ }^{\circ} \mathrm{C}$ with Ulp protease to remove the SUMO tag. The eluate was dialyzed against buffer F1 (20 mM Tris-HCL pH 7.9, 2\% glycerol, $100 \mathrm{mM} \mathrm{NaCl}, 4 \mathrm{mM} \beta$-mercaptoethanol) and loaded onto three 1-ml columns (SP HP, His-trap HP, and heparin HP, $1 \mathrm{ml}$ each, GE healthcare) connected in a series. After washing the columns with buffer F1, SP and His columns were disconnected, and a linear salt gradient from buffer F1 to buffer F2 (20 mM Tris-HCL pH 7.9, 2\% glycerol, $1000 \mathrm{mM} \mathrm{NaCl}, 4 \mathrm{mM} \beta$-ME) was applied to elute PrimPol from the heparin column. PrimPol was eluted at $200 \mathrm{mM} \mathrm{NaCl}$. Protein samples were aliquoted, frozen in liquid nitrogen and stored at $-80^{\circ} \mathrm{C}$. PrimPol D114A mutant variant was obtained by site-directed mutagenesis and purified as the wild-type enzyme. PrimPol R47A and R76A mutant variants were purified as described ${ }^{46}$.

The full-length human PolDIP2 was purified from E. coli as described ${ }^{38}$. Four-subunit yeast Pol $\zeta$ was purified from $20 \mathrm{~L}$ of Saccharomyces cerevisiae culture as described ${ }^{69}$. To create the yeast expression vector encoding for human Pol $\eta$ fused with the N-terminal GST-tag, the chemically synthesized and optimized to yeast codon usage $P O L H$ gene was cloned in the pRS424-GAL-GST-TRP plasmid under the chimeric GAL1-GAL10 promoter ${ }^{70}$. Pol $\eta$ was purified from $10 \mathrm{~L}$ of $S$. cerevisiae culture using the Pol $\zeta$ protocol. Human Pol $\beta$ was purified from $3 \mathrm{~L}$ of $E$. coli as described ${ }^{71}$. Human Pol $\kappa$ was kindly provided by Dr. Leonid Gening (IMG, Moscow). E. coli formamidopyrimidine-DNA glycosylase (Fpg) was overexpressed and purified as described ${ }^{66}$. PrimPol, PolDIP2, Pol $\eta$ and Pol $\zeta$ preparations are shown in Supplementary Figure 7.

DNA oligonucleotide substrates. Unmodified DNA oligonucleotides were purchased from Syntol (Moscow, Russia). Oligonucleotides containing 8-oxoG were synthesized by the ICBFM Laboratory of Medicinal Chemistry (Novosibirsk, Russia). To obtain the substrates for DNA polymerase reactions, the primers were $5^{\prime}$-labeled with $\left[\gamma^{-32} \mathrm{P}\right]$-ATP by T4 polynucleotide kinase and annealed to the corresponding unlabeled template oligonucleotides. The sequences of the oligonucleotides used in this study are shown in Table 1 and the positions of cross-links are indicated.

Preparation of the 1,2-GG cisplatin CL. Cisplatinated oligonucleotide was prepared according to ${ }^{72}$ with $^{\text {. }}$ modifications. To replace chloride ligands by $\mathrm{H}_{2} \mathrm{O}$ (cisplatin activation), cisplatin $(4.5 \mathrm{mg}, 15 \mu \mathrm{mol}, 1.0 \mathrm{~mol} \mathrm{eq}$, Sigma-Aldrich. St. Louis, MO) was dissolved in $980 \mu \mathrm{L} \mathrm{H}_{2} \mathrm{O}$, mixed with $20 \mu \mathrm{lgNO}_{3}$ solution $(1.5 \mathrm{M}, 30 \mu \mathrm{mol}$, 


\begin{tabular}{|l|l|}
\hline Template-CL & $\begin{array}{l}\text { 5'-CCTCCTTCTCCTTGGTCATCTATCCCTTCT-3' } \\
\text { GG or 1,2-GG CisPt CL }\end{array}$ \\
\hline Primer CL-13 & 5'-AGAAGGGATAGAT-3' \\
\hline Primer CL-15 & 5'-AGAAGGGATAGATGA-3' \\
\hline Primer CL-16 T & 5'-AGAAGGGATAGATGAT-3' \\
\hline Primer CL-16C & 5'-AGAAGGGATAGATGAC-3' \\
\hline Primer CL-17CC & 5'-AGAAGGGATAGATGACC-3' \\
\hline Primer DpCL-11 & 5'-CGAGACCGTCG-3' \\
\hline Downstream_primer_oG DpCL-28 & $\begin{array}{l}\text { 5'-GAGGAAAGAAGX_GAAGGAATTCCAGAGC-3' } \\
\text { X=8-oxoG }\end{array}$ \\
\hline Downstream_primer DpCL-28 & 5'-GAGGAAAGAAGCGAAGGAATTCCAGAGC-3' \\
\hline Template_oG DpCL-40 & $\begin{array}{l}\text { 5'-GCTCTGGAATTCCTTCXXCTTCTTTCCTCTCGACGGTCTCG-3' } \\
\text { X=8-oxoG }\end{array}$ \\
\hline Template DpCL-40 & 5'-GCTCTGGAATTCCTTCCCTTCTTTCCTCTCGACGGTCTCG-3' \\
\hline Marker DpCL-23 & 5'-CGAGACCGTCGCGAGGAAAGAAG-3' \\
\hline Marker DpCL-40 & 5'-CGAGACCGTCGCGAGGAAAGAAGCGAAGGAATTCCAGAGC-3' \\
\hline Template-CPD & $\begin{array}{l}\text { 5'-GGGCAGCTCAAGTAACTTGGCCTGGTCATT-3' } \\
\text { TT or } \text { cis-syn CPD }\end{array}$ \\
\hline Primer CPD-11 & 5'-AATGACCAGGC-3' \\
\hline
\end{tabular}

Table 1. Oligonucleotides used in the study.

$2.0 \mathrm{~mol} \mathrm{eq}$ ) and incubated in the dark for $24 \mathrm{~h}$ at $37^{\circ} \mathrm{C}$ and vigorous shaking (1000 rpm). The AgCl precipitate was centrifuged (13,000 rpm, $5 \mathrm{~min}$ ) and the supernatant containing $15 \mathrm{mM}$ activated cisplatin was collected. $100 \mu \mathrm{l}$ of $1 \mathrm{mM}$ single stranded DNA with a unique GG sequence $(100 \mathrm{nmol}, 1 \mathrm{~mol}$ eq) were mixed with $20 \mu \mathrm{l}$ activated cisplatin solution ( $300 \mathrm{nmol}, 3 \mathrm{~mol} \mathrm{eq}$ ) and $880 \mu \mathrm{l} 113.6 \mathrm{mM} \mathrm{NaClO}_{4} \mathrm{pH}^{2} .2$ (final concentration $100 \mathrm{mM}$ ). The reaction mixture was incubated in the dark for $5 \mathrm{~h}$ at $37^{\circ} \mathrm{C}$.

Oligonucleotide containing a cisplatin adduct was purified by anion exchange FPLC as described previously ${ }^{73}$. Briefly, the DNA sample was diluted tenfold with buffer A $(0.1 \mathrm{M} \mathrm{NaCl}, 10 \mathrm{mM}$ Tris-HCl, $\mathrm{pH} 7.4)$ and loaded onto a Mono Q 5/50 GL column (GE healthcare). DNA reaction products were eluted by three-step gradient with buffer B (1 M NaCl, 10 mM Tris- $\mathrm{HCl}$ pH 7.4): 10-37\% buffer B in 5 column volumes, $37-47 \%$ buffer B in 40 column volumes, and $47-100 \%$ buffer B in 1 column volume at a flow rate of $0.5 \mathrm{~mL} / \mathrm{min}$. The cisplatin adduct was eluted at $0.4 \mathrm{M} \mathrm{NaCl}$ in the first peak. The purity of platinated DNA was confirmed by $21 \% / 8 \mathrm{M}$ urea PAGE (Supplementary Figure 1).

Preparation of DNA-protein cross-links. Model DpCLs were prepared as described in ${ }^{33}$. The reaction mixture contained $50 \mathrm{mM}$ sodium phosphate ( $\mathrm{pH}$ 6.8), $1 \mathrm{mM}$ EDTA, $1 \mathrm{mM}$ DTT and 30 pmol of one of the 8-oxoG-containing oligonucleotide substrates: single-stranded Template_oG DpCL-40 or duplexes Downstream_primer DpCL-28//Template_oG DpCL-40 and Downstream_primer_oG DpCL-28//Template DpCL40 , containing 8-oxoG in the template strand or in the downstream primer respectively. A 20 -fold molar excess of Fpg and $100 \mathrm{mM} \mathrm{NaBH}_{4}$ were added simultaneously. The reaction was allowed to proceed for $1 \mathrm{~h}$ at $37^{\circ} \mathrm{C}$ and stopped by adding glucose to $400 \mathrm{mM}$ and incubating for $30 \mathrm{~min}$ on ice. The DNA-Fpg DpCL was purified by $8 \%$ native PAGE; the band of interest was excised, eluted overnight with $0.1 \times \mathrm{TE}$ buffer, and the solution was passed through a $0.22-\mu \mathrm{m}$ pore filter (Ultrafree CL, Merck Millipore, Burlington, MA) and concentrated in a Centricon-10 ultrafiltration unit (Merck Millipore). The efficiency of cross-linking and the purity of DpCLs after purification and concentration was confirmed by SDS-PAGE. To complete the assembly of DpCLs containing substrate, an equimolar amount of the ${ }^{32} \mathrm{P}$-labeled primer (Primer DpCL-11) was added and incubated for $30 \mathrm{~min}$ at room temperature. As controls for DNA polymerase reactions, we used undamaged constructs: primer-template (Primer DpCL-11//Template DpCL-40) or primer-downstream primer-template (Primer DpCL-11 Downstream_primer DpCL-28//Template DpCL-40).

Primer extension reactions. Primer extension reactions were carried out in $20 \mu$ of the reaction buffer containing $30 \mathrm{mM}$ HEPES (pH 7.0), $5 \%$ glycerol, $0.1 \mathrm{mg} / \mathrm{ml}$ bovine serum albumin, $10 \mathrm{mM} \mathrm{MgCl}{ }_{2}$ or $0.5 \mathrm{mM}$ $\mathrm{MnCl}_{2}, 20 \mathrm{nM}$ DNA substrate, $200 \mu \mathrm{M}$ dNTPs and $200 \mathrm{nM}$ PrimPol (or $100-600 \mathrm{nM}$ PrimPol) and $300 \mathrm{nM}$ PolDIP2, $5 \mathrm{nM}$ Pol $\kappa$ or $30 \mathrm{nM}$ Pol $\zeta$. In control experiments, $10 \mathrm{nM}$ Pol $\eta$ or Pol $\beta$ were used in the reactions. Reactions were started by adding dNTPs and were incubated at $37^{\circ} \mathrm{C}$ for specified time $(2-30 \mathrm{~min})$. The reactions were terminated by adding $20 \mu \mathrm{l}$ of loading buffer containing 95\% formamide, $10 \mathrm{mM}$ EDTA and $0.1 \%$ bromophenol blue. DNA products were heated at $95^{\circ} \mathrm{C}$ for $2 \mathrm{~min}$ and resolved on $21 \%$ polyacrylamide gels containing $8 \mathrm{M}$ urea, followed by phosphorimaging on Typhoon 9400 (GE Healthcare). Experiments were repeated 2-4 times.

\section{Data availability}

The data that support the findings of this study are included in the Supplementary Information file or are available from the corresponding author on request. 
Received: 14 March 2021; Accepted: 26 July 2021

Published online: 02 September 2021

\section{References}

1. Bianchi, J. et al. Primpol bypasses UV photoproducts during eukaryotic chromosomal DNA replication. Mol. Cell 52, 566-573 (2013).

2. García-Gómez, S. et al. PrimPol, an archaic primase/polymerase operating in human cells. Mol. Cell 52, 541-553 (2013).

3. Bailey, L. J., Bianchi, J. \& Doherty, A. J. PrimPol is required for the maintenance of efficient nuclear and mitochondrial DNA replication in human cells. Nucleic Acids Res. 47, 4026-4038 (2019).

4. Kobayashi, K. et al. Repriming by PrimPol is critical for DNA replication restart downstream of lesions and chain-terminating nucleosides. Cell Cycle 15, 1997-2008 (2016).

5. Mourón, S. et al. Repriming of DNA synthesis at stalled replication forks by human PrimPol. Nat. Struct. Mol. Biol. 20, 1383-1389 (2013).

6. Torregrosa-Muñumer, R. et al. PrimPol is required for replication reinitiation after mtDNA damage. Proc. Natl. Acad. Sci. U. S. A. 114, 11398-11403 (2017).

7. Schiavone, D. et al. PrimPol is required for replicative tolerance of G quadruplexes in vertebrate cells. Mol. Cell 61, 161-169 (2016).

8. Piberger, A. L. et al. PrimPol-dependent single-stranded gap formation mediates homologous recombination at bulky DNA adducts. Nat. Commun. 11, 5863 (2020).

9. Quinet, A. et al. PRIMPOL-Mediated Adaptive Response Suppresses Replication Fork Reversal in BRCA-Deficient Cells. Mol. Cell 77, 461-474.e9 (2019).

10. Makarova, A. V., Boldinova, E. O., Belousova, E. A. \& Lavrik, O. I. In vitro lesion bypass by human PrimPol. DNA Repair (Amst.) 70, 18-24 (2018)

11. Zafar, M. K., Ketkar, A., Lodeiro, M. F., Cameron, C. E. \& Eoff, R. L. Kinetic analysis of human PrimPol DNA polymerase activity reveals a generally error-prone enzyme capable of accurately bypassing 7,8-dihydro-8-oxo-2'-deoxyguanosine. Biochemistry 53, 6584-6594 (2014).

12. Martínez-Jiménez, M. I. et al. Alternative solutions and new scenarios for translesion DNA synthesis by human PrimPol. DNA Repair (Amst). 29, 127-138 (2015).

13. Martínez-Jiménez, M. I., Lahera, A. \& Blanco, L. Human PrimPol activity is enhanced by RPA. Sci. Rep. 7, 783 (2017).

14. Guilliam, T. A. et al. Molecular basis for PrimPol recruitment to replication forks by RPA. Nat. Commun. 8, 15222 (2017).

15. Wan, L. et al. HPrimpol1/CCDC111 is a human DNA primase-polymerase required for the maintenance of genome integrity. EMBO Rep. 14, 1104-1112 (2013).

16. Guilliam, T. A., Bailey, L. J., Brissett, N. C. \& Doherty, A. J. PolDIP2 interacts with human PrimPol and enhances its DNA polymerase activities. Nucleic Acids Res. 44, 3317-3329 (2016).

17. Dasai, S. \& Tchounwou, P. B. Cisplatin in cancer therapy: molecular mechanisms of action. Eur. J. Pharmacol. 740, 364-378 (2014).

18. Natile, G. \& Cannito, F. Platinum Drugs, Nucleotides and DNA: The Role of Interligand Interactions, In: N. Hadjiliadis and E. Sletten, Eds., Metale Complex-DNA Interactious, Blackwell Publishing Ltd., Chichester, 135-173 (2009).

19. Hoffmann, J. et al. DNA polymerase beta bypasses in vitro a single d ( GpG ) -cisplatin adduct placed on codon 13 of the HRAS gene. Proc. Natl. Acad. Sci. U. S. A. 92, 5356-5360 (1995).

20. Shi, L. et al. Premature p34cdc2 activation required for apoptosis. Science. 263, 1143-1145 (1994).

21. Shapiro, G. I. \& Harper, J. W. Anticancer drug targets: Cell cycle and checkpoint control. J. Clin. Invest. 104, 1645-1653 (1999).

22. Jamieson, E. R. \& Lippard, S. J. Structure, recognition, and processing of cisplatin-DNA adducts. Chem. Rev. 99, 2467-2498 (1999).

23. Shilkin, E. S. et al. Translesion DNA synthesis and reinitiation of DNA synthesis in chemotherapy resistance. Biochem. 85, 869-882 (2020).

24. Kojima, Y. \& Machida, Y. J. DNA-protein crosslinks from environmental exposure: Mechanisms of formation and repair. Env. Mol. Mutagen. 61, 716-729 (2020).

25. Kow, Y. W. \& Wallace, S. S. Mechanism of action of Escherichia coli endonuclease III. Biochemistry 26, 8200-8206 (1987).

26. Hashimoto, M., Greenberg, M. M., Kow, Y. W., Hwang, J. \& York, N. The 2-deoxyribonolactone lesion produced in DNA by neocarzinostatin and other damaging agents forms cross-links with the base-excision repair enzyme endonuclease III. J. Am. Chem. Soc. 123, 3161-3162 (2001).

27. Kroeger, K. M., Hashimoto, M., Kow, Y. W. \& Greenberg, M. M. Cross-linking of 2-deoxyribonolactone and its $\beta$-elimination product by base excision repair enzymes. Biochemistry 42, 2449-2455 (2003).

28. Nakano, T. et al. Homologous recombination but not nucleotide excision repair plays a pivotal role in tolerance of DNA-protein cross-links in mammalian cells. J. Biol. Chem. 284, 27065-27076 (2009).

29. Guan, L. \& Greenberg, M. M. Irreversible inhibition of DNA polymerase $\beta$ by an oxidized abasic lesion. J. Am. Chem. Soc. 132, 5004-5005 (2010).

30. Guan, L., Bebenek, K., Kunkel, T. A. \& Greenberg, M. M. Inhibition of short patch and long patch base excision repair by an oxidized abasic site. Biochemistry 49, 9904-9910 (2010).

31. Prasad, R. et al. Suicidal cross-linking of PARP-1 to AP site intermediates in cells undergoing base excision repair. Nucleic Acids Res. 42, 6337-6351 (2014).

32. Kuo, H. K., Griffith, J. D. \& Kreuzer, K. N. 5-Azacytidine-induced methyltransferase-DNA adducts block DNA replication in vivo. Cancer Res. 67, 8248-8254 (2007).

33. Yudkina, A. V., Dvornikova, A. P. \& Zharkov, D. O. Variable termination sites of DNA polymerases encountering a DNA-protein cross-link. PLoS ONE 13, e0198480 (2018).

34. Ji, S. et al. Transcriptional bypass of DNA-protein and DNA-peptide conjugates by T7 RNA polymerase. ACS Chem. Biol. 14, 2564-2575 (2019).

35. Chvalova, K., Brabec, V. \& Kasparkova, J. Mechanism of the formation of DNA - protein cross-links by antitumor cisplatin. Nucleic Acids Res. 35, 1812-1821 (2007).

36. Duxin, J. P., Dewar, J. M., Yardimci, H. \& Walter, J. C. Repair of a DNA-protein crosslink by replication-coupled proteolysis. Cell 159, 346-357 (2014).

37. Kühbacher, U. \& Duxin, J. P. How to fix DNA-protein crosslinks. DNA Repair (Amst). 94, 102924 (2020).

38. Boldinova, E. O. et al. Strand displacement activity of primpol. Int. J. Mol. Sci. 21, 9027 (2020).

39. Carpio, R. V. et al. Role of human DNA polymerase $\kappa$ in extension opposite from a cis-syn thymine dimer. J. Mol. Biol. 408, 252-261 (2011).

40. Johnson, R. E., Washington, M. T., Haracska, L., Prakash, S. \& Prakash, L. Eukaryotic polymerases i and $\mathrm{z}$ act sequentially to bypass DNA lesions. Nature 406, 1015-1019 (2000).

41. Lee, Y., Gregory, M. T. \& Yang, W. Human Pol $\zeta$ purified with accessory subunits is active in translesion DNA synthesis and complements Pol $\eta$ in cisplatin bypass. Proc. Natl Acad. Sci. U. S. A.111, 2954-2959 (2014).

42. Washington, M. T. et al. Efficient and error-free replication past a minor-groove N2-guanine adduct by the sequential action of yeast Rev1 and DNA polymerase zeta. Mol. Cell. Biol. 24, 6900-6906 (2004). 
43. Alt, A. et al. Bypass of DNA lesions generated during anticancer treatment with cisplatin by DNA polymerase h. Nature 318, 967-970 (2007).

44. Masutani, C. Mechanisms of accurate translesion synthesis by human DNA polymerase eta. EMBO J. 19, 3100-3109 (2000).

45. Rechkoblit, O. et al. Structure and mechanism of human PrimPol, a DNA polymerase with primase activity. Sci. Adv. 2, e1601317 (2016).

46. Boldinova, E. O., Manukyan, A. A. \& Makarova, A. V. The DNA ligands Arg47 and Arg76 are crucial for catalysis by human PrimPol. DNA Repair (Amst). 100, 103048 (2021).

47. Stehlikova, K., Kostrhunova, H., Kasparkova, J. \& Brabec, V. DNA bending and unwinding due to the major 1,2-GG intrastrand cross-link formed by antitumor cis-diamminedichloroplatinum(II) are flanking-base independent. Nucleic Acids Res. 30, 2894-2898 (2002).

48. Mcdonald, J. P. et al. DNA polymerase iota and related Rad30-like enzymes. Phil. Trans. R. Soc. L. 356, 53-60 (2001).

49. Maga, G. et al. Human DNA polymerase lambda functionally and physically interacts with proliferating cell nuclear antigen in normal and translesion DNA synthesis*. J. Biol. Chem. 277, 48434-48440 (2002).

50. Vaisman, A. et al. Effect of DNA polymerases and high mobility group protein 1 on the carrier ligand specificity for translesion synthesis past platinum-DNA adducts. Biochemistry 38, 11026-11039 (1999).

51. Vaisman, A., Masutani, C., Hanaoka, F. \& Chaney, S. G. Efficient translesion replication past oxaliplatin and cisplatin GpG adducts by human DNA polymerase eta. Biochemistry 39, 4575-4580 (2000).

52. Vaisman, A., Warren, M. W. \& Chaney, S. G. The effect of DNA structure on the catalytic efficiency and fidelity of human DNA polymerase $\beta$ on templates with platinum-DNA adducts. J. Biol. Chem. 276, 18999-19005 (2001).

53. Bassett, E. et al. Efficiency of extension of mismatched primer termini across from cisplatin and oxaliplatin adducts by human DNA polymerases $\beta$ and $\eta$ in vitro. Biochemistry 42, 14197-14206 (2003).

54. Wu, F., Lin, X., Okuda, T. \& Howell, S. B. DNA polymerase zeta regulates cisplatin cytotoxicity, mutagenicity, and the rate of development of cisplatin resistance. Cancer Res. 64, 8029-8035 (2004).

55. Sharma, S., Shah, N. A., Joiner, A. M., Roberts, K. H. \& Canman, C. E. DNA polymerase $\zeta$ is a major determinant of resistance to platinum-based chemotherapeutic agents. Mol. Pharmacol. 81, 778-787 (2012).

56. Bezalel-Buch, R., Cheun, Y. K., Roy, U., Schärer, O. D. \& Burgers, P. M. Bypass of DNA interstrand crosslinks by a Rev1-DNA polymerase $\zeta$ complex. Nucleic Acids Res. 48, 8461-8473 (2020).

57. Haracska, L., Prakash, S. \& Prakash, L. Yeast DNA polymerase $\zeta$ is an efficient extender of primer ends opposite from 7,8-dihydro8-oxoguanine and O6-methylguanine. Mol. Cell. Biol. 23, 1453-1459 (2003).

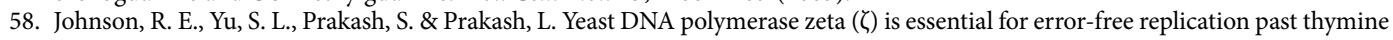
glycol. Genes Dev. 17, 77-87 (2003).

59. Shachar, S. et al. Two-polymerase mechanisms dictate error-free and error-prone translesion DNA synthesis in mammals. EMBO J. 28, 383-393 (2009).

60. Jha, V. \& Ling, H. Structural basis for human DNA polymerase kappa to bypass cisplatin intrastrand cross-link (Pt-GG) lesion as an efficient and accurate extender. J. Mol. Biol. 430, 1577-1589 (2018).

61. Olivero, O. A., Chang, P. K., Lopez-Larraza, D. M., Semino-Mora, M. C. \& Poirier, M. C. Preferential formation and decreased removal of cisplatin-DNA adducts in Chinese hamster ovary cell mitochondrial DNA as compared to nuclear DNA. Mutat. Res. Genet. Toxicol. Environ. Mutagen. 391, 79-86 (1997).

62. Singh, B. et al. Human REV3 DNA polymerase zeta localizes to mitochondria and protects the mitochondrial genome. PLoS ONE 10, $\mathrm{e} 0140409$ (2015).

63. Yeo, J. E. et al. Synthesis of site-specific DNA-protein conjugates and their effects on DNA replication. ACS Chem. Biol. 9, 1860-1868 (2014).

64. Wickramaratne, S. et al. Bypass of DNA-protein cross-links conjugated to the 7-deazaguanine position of DNA by translesion synthesis polymerases. J. Biol. Chem. 291, 23589-23603 (2016).

65. Yudkina, A. V. et al. Displacement of slow-turnover DNA glycosylases by molecular traffic on DNA. Genes (Basel) 11, 866 (2020).

66. Gilboa, R. et al. Structure of formamidopyrimidine-DNA glycosylase covalently complexed to DNA. J. Biol. Chem. 277, 1981119816 (2002).

67. Vashishtha, A. K., Wang, J. \& Konigsberg, W. H. Different divalent cations alter the kinetics and fidelity of DNA. J. Biol. Chem. 291, 20869-20875 (2016).

68. Keen, B. A., Jozwiakowski, S. K., Bailey, L. J., Bianchi, J. \& Doherty, A. J. Molecular dissection of the domain architecture and catalytic activities of human PrimPol. Nucleic Acids Res. 42, 5830-5845 (2014).

69. Makarova, A. V., Stodola, J. L. \& Burgers, P. M. A four-subunit DNA polymerase $\zeta$ complex containing Pol $\delta$ accessory subunits is essential for PCNA-mediated mutagenesis. Nucleic Acids Res. 40, 11618-11626 (2012).

70. Makarova, A. V. et al. Inaccurate DNA synthesis in cell extracts of yeast producing active human DNA polymerase iota. PLoS ONE 6, e16612 (2011).

71. Shilkin, E. S., et al. Template properties of 5-methyl-2'-deoxycytidine and 5-hydroxymethyl-2'-deoxycytidine in reactions with human translesion and reparative DNA polymerases. Mol. Biol. (Mosk) 55, 267-272 (2021)

72. Schneider, S., Reißner, T., Ziv, O., Livneh, Z. \& Carell, T. Translesion synthesis of 1,3-GTG sisplatin DNA lesions. ChemBioChem 11, 1521-1524 (2010).

73. Enoiu, M., Ho, T. V., Long, D. T., Walter, J. C. \& Schärer, O. D. Construction of plasmids containing site-specific DNA interstrand cross-links for biochemical and cell biological studies. Methods Mol. Biol. 920, 203-219 (2012).

\section{Author contributions}

E.O.B., E.S.S., A.V.Y. and D.I.G. carried out the experiment. A.V.Y., A.V.M., A.G.B., T.H.T. and D.O.Z. wrote the manuscript.

\section{Funding}

This work was supported by the Russian Science Foundation Grant 18-14-00354 (to AVM) (experiments with cisplatin cross-link and the wild-type PrimPol). This work was also partially supported by theRussian Foundation for Basic Research Grant 19-34-90147 (to AVM) and National Institute of General Medical Sciences R35 GM127085 (to THT) (experiments with PrimPol mutants), and the Russian Foundation for Basic Research Grant 17-00-00261/17-00-00264 (to DOZ/AVM) and Russian Presidential Fellowship SP-174.2021.4 (to AVY) (part with DNA-protein cross-links).

\section{Competing interests}

The authors declare no competing interests. 


\section{Additional information}

Supplementary Information The online version contains supplementary material available at https://doi.org/ 10.1038/s41598-021-96692-y.

Correspondence and requests for materials should be addressed to A.V.M.

Reprints and permissions information is available at www.nature.com/reprints.

Publisher's note Springer Nature remains neutral with regard to jurisdictional claims in published maps and institutional affiliations.

(c) (1) Open Access This article is licensed under a Creative Commons Attribution 4.0 International cc) License, which permits use, sharing, adaptation, distribution and reproduction in any medium or format, as long as you give appropriate credit to the original author(s) and the source, provide a link to the Creative Commons licence, and indicate if changes were made. The images or other third party material in this article are included in the article's Creative Commons licence, unless indicated otherwise in a credit line to the material. If material is not included in the article's Creative Commons licence and your intended use is not permitted by statutory regulation or exceeds the permitted use, you will need to obtain permission directly from the copyright holder. To view a copy of this licence, visit http://creativecommons.org/licenses/by/4.0/.

(C) The Author(s) 2021 